\title{
The effectiveness of hydrocolloid dressings versus other dressings in the healing of pressure ulcers in adults and older adults: a systematic review and meta-analysis ${ }^{1}$
}

\author{
Franciele Soares Pott ${ }^{2}$ \\ Marineli Joaquim Meier ${ }^{3}$ \\ Janislei Giseli Dorociak Stocco ${ }^{4}$ \\ Karla Crozeta ${ }^{5}$ \\ Janyne Dayane Ribas ${ }^{6}$
}

Objective: to evaluate the effectiveness of hydrocolloids in the healing of pressure ulcers in adult and older adult patients. Method: systematic review with meta-analysis, based on the recommendations of the Cochrane Handbook. The search was undertaken in the databases: Medical Literature Analysis and Retrieval System Online, Latin American and Caribbean Health Sciences Literature (LILACS), Cochrane Database, Cumulative Index to Nursing and Allied Health Literature, Web of Science and the Scientific Electronic Library Online. Results: 646 primary studies were identified, 69 were evaluated and nine were selected, referring to the use of the hydrocolloid dressing in healing; of these, four studies allowed meta-analysis. There was no statistically significant difference between the hydrocolloid group and the foams group ( $p$ value=0.84; Odds Ratio 1.06, CI 95\% 0.61-1.86). A slight superiority of the polyurethane dressings was observed in relation to the hydrocolloid dressings. Conclusion: the evidence is not sufficient to affirm whether the efficacy of hydrocolloid dressings is superior to that of other dressings. It is suggested that clinical randomized trials be undertaken so as to ascertain the efficacy of this intervention in the healing of pressure ulcers, in relation to other treatments.

Descriptors: Pressure Ulcer; Bandages, Hydrocolloid; Wound Healing; Meta-Analysis.

\footnotetext{
${ }^{1}$ Paper extracted from master's thesis "Use of Hydrogel andhydrocolloid in Pressure Ulcer: Systematic Review and Meta-Analysis" presented to Universidade Federal do Paraná, Curitiba, PR, Brazil.

${ }^{2}$ MSc, RN, Secretaria Estadual de Segurança Pública, Curitiba, PR, Brazil.

${ }^{3} \mathrm{PhD}$, Associate Professor, Departamento de Enfermagem, Universidade Federal do Paraná, Curitiba, PR, Brazil.

${ }^{4}$ Doctoral student, Universidade Federal do Paraná, Curitiba, PR, Brazil.

${ }^{5} \mathrm{PhD}$, Adjunct Professor, Universidade Federal do Paraná, Curitiba, PR, Brazil.

${ }^{6}$ MSc, Professor, Universidade Federal do Paraná, Curitiba, PR, Brazil.
}

Corresponding Author:

Franciele Soares Pott

Universidade Federal do Paraná. Departamento de Enfermagem

Av. Pref. Lothário Meissner, 632

Jardim Botânico

CEP: 80210-170, Curitiba, PR, Brasil

E-mail: franzinha_soares@yahoo.com.br
Copyright (๑) 2014 Revista Latino-Americana de Enfermagem This is an Open Access article distributed under the terms of the Creative Commons Attribution Non-Commercial License (CC BY-NC).

This license lets others distribute, remix, tweak, and build upon your work non-commercially, and although their new works must also acknowledge you and be non-commercial, they don't have to license their derivative works on the same terms. 


\section{Introduction}

The healing of chronic wounds takes over eight weeks, even with the care spent on the wound(1); such wounds affect approximately $1 \%$ of the population (4-5 $\%$ over 80 years old) ${ }^{(2)}$ with a prognosis of non-healing at $20 \%$ at two years, $8 \%$ at five years and annual recurrence in $6-15 \%{ }^{(3)}$.

Healing follows a specific chronological sequence, with three interdependent and overlapping phases (inflammatory, proliferative, and maturation or remodelling), and involves complex cellular and biochemical events, with the interaction between the cells, the extracellular matrix, and plasma proteins coordinated by cytosines and growth factors, in a dynamic and successive process. This sequence, when interrupted, promotes the chronicity of the wound ${ }^{(4)}$.

Among the chronic wounds with worldwide importance, one finds the pressure ulcers (PU), defined as a localized injury to the skin and/or underlying tissue usually over a bony prominence, as a result of pressure, or pressure in combination with shear ${ }^{(5)}$. They affect thousands of people around the world at the different levels of health care, with the adult and older adult population standing out. In the United States of America (USA), each year, approximately 3,000,000 people develop PU. Of these, over 60,000 die each year as a result of the complications caused by the lesion's presence $^{(6)}$

Studies on the prevalence and incidence of PU indicate alarming rates. Works undertaken in the USA indicate that the prevalence varies from 10 to $18 \%$ in critical environments and from 0 to $29 \%$ in home care; with incidences from 0.4 to $38 \%$ and from 0 to $17 \%$ respectively ${ }^{(7)}$. In Brazil, there are, as yet, no studies presenting the national rates of the occurrence of this lesion, however, works undertaken in different parts of the country demonstrate high numbers ${ }^{(8-9)}$.

In order to reduce the alarming levels of prevalence and incidence of PU worldwide, international organizations (the European Pressure Ulcer Advisory Panel (EPUAP); the National Pressure Ulcer Advisory Panel (NPUAP); the Agency for Health Care Policy and Research (AHCPR) and the National Institute for Health and Clinical Excellence (NICE)) have elaborated clinical guidelines directed towards the prevention and treatment of this health problem. Among the technologies directed towards treating $\mathrm{PU}$, the guidelines(5) indicate the hydrocolloids as a possibility for local therapy, based on the classification and on the characteristics of the wound.
The hydrocolloids are interactive dressings, made up of an external layer of polyurethane and an internal layer of gelatine, pectin and carboxymethyl cellulose, which produce an ideal humid environment in the wound bed, control the exudate, facilitate the autolytic debridement, contribute to pain management and provide a barrier to external microorganisms ${ }^{(6)}$.

Added to this, the hydrocolloids maintain an acid $\mathrm{pH}$ in the wound bed, which impedes bacterial growth, as well as sustaining an ideal local temperature. They promote angiogenesis, increase the number of fibroblasts of the dermis, encourage the production of granulation tissue and increase the quantity of synthesized collagen, all of which are essential in the healing process ${ }^{(10)}$.

Besides the hydrocolloids, other dressings such as hydrogels, polyurethane foams, and hydropolymers, among others, help in the healing process. However, evaluation of the evidence regarding the effectiveness of these therapies for better PU healing, or regarding which product is most appropriate for each stage of the pressure ulcer(11-12) remains scarce. Thus, the present study aimed to evaluate the effectiveness of hydrocolloids in the healing of pressure ulcers in adults and older adult patients.

\section{Method}

This is a Systematic Review with meta-analysis, undertaken in the Nursing Department, Postgraduate Nursing Program, Health Sciences Department, at the Federal University of Paraná.

Study protocol: the recommendations of the Cochrane Handbook ${ }^{(13)}$ for undertaking systematic reviews and meta-analysis were followed. The PICO method was used for elaborating the review question ${ }^{(14)}$. This included randomized clinical trials, whose participants were adults and older adults with PU, either receiving inpatient treatment or not, receiving treatments with hydrocolloid dressings and who presented the cure/healing of the ulcer as an outcome, in the English, Spanish and Portuguese languages.

The exclusion criteria were studies which did not address adults and older adult patients, did not use hydrocolloid dressings, were published in years before 1994, and which were classified as C and D in the evaluation of allocation concealment.

\section{Strategy for identifying the studies}

The relevant studies were selected using an electronic search in five databases from the health 
area, namely: Medical Literature Analysis and Retrieval System Online (MEDLINE/PUBMED), Latin American and Caribbean Health Sciences Literature (LILACS/ BIREME), Cochrane Database (COCHRANE DATABASE), Cumulative Index to Nursing and Allied Health Literature (CINAHL), Web of Science (WEB OF SCIENCE) and Scientific Electronic Library Online (SciELO). Also undertaken was a manual search of the references cited in the articles selected, systematic review articles published and identified, potentially useful studies, reviews of congress proceedings involving PU or wounds, and websites researched in searching for clinical trials (http://www.controlled-trials.com; http://www.updatesoftware.com; http://.clinicaltrialresults.org; http:// centrewatch.com; http://www.clinicaltrial.gov).

The main descriptors adopted in the search strategy for primary studies were: Pressure Ulcer, Bandages, Occlusive dressings, Bandages Hydrocolloids, Therapeutics, Treatment Outcome, Wound Healing, Granulation Tissue and Debridement, combined using the Boolean operators AND and OR.

Figure 1 presents the search strategy adopted in the MEDLINE database via PUBMED, which was adapted for the other databases analyzed.

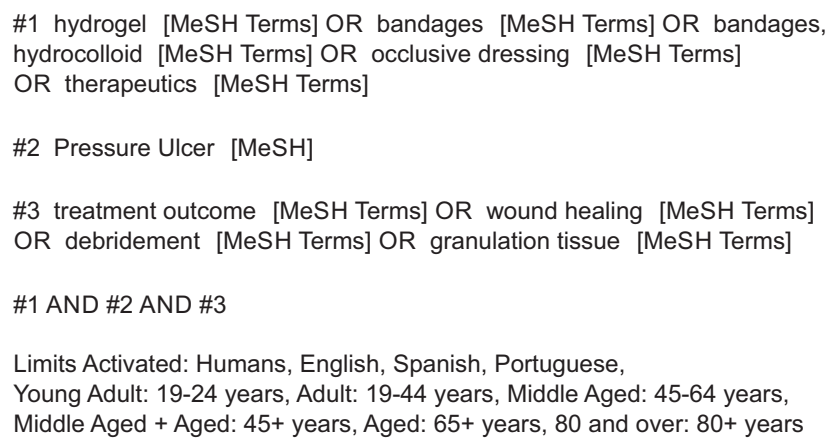

Figure 1 - Search strategy in the Medline/Pubmed databases

\section{Selection of the studies}

For selecting the studies, two independent reviewers analyzed the titles and the abstracts of the publications identified. In the event of doubt or disagreement, a third reviewer was asked to give an opinion regarding the inclusion or not of the study in question. The degree of agreement between the reviewers was established using the kappa coefficient ${ }^{(15)}$, and the level reached was 0.783 .

\section{Evaluation of the methodological quality}

The evaluation of the methodological quality of the studies selected used the Jadad scale(16), which evaluates and scores five specific topics: 1 . Was the study described as randomized? ; 2 . Was the method of randomization appropriate?; 3. Was the study described as double blind?; 4 . Was the method of blinding used appropriate?; 5. Was there a description of withdrawals and dropouts?

The studies were classified in three categories ( $A$, B and $C$ ), in accordance with the allocation concealment $^{(13)}$.

\section{Extraction of the data and statistical analysis}

For extraction of the data, a predefined form was used, which covered the following information: identification of the studies (title, Journal, year of publication, volume, number, authors); objetives; method (method of randomization, blinding, number of randomized patients, description of follow-up losses, inclusion and exclusion criteria, age, standard deviation and sex, stage of the PU and clinical characteristics, intervention in the experimental group and control group) and outcomes.

The data were stratified and analyzed by outcomes. For statistical analysis, the researchers used the Bioestata $5.3 \AA$ program and the Review Manager 5.0, made available by The Cochrane Collaboration. As dichotomous variables were involved, the odds ratio (OR) was used, with a respective confidence interval of 95\% (fixed effect model). For calculating heterogeneity, the Mantael-Haenzel chi-squared test and the $\mathrm{I}^{2}$ were appropriate. One guide for interpreting the $\mathrm{I}^{2}$ is described as follows: 0 to $40 \%$ : must not be considered relevant; 30 to $60 \%$ : may represent moderate heterogeneity; 50 
to $90 \%$ : may represent large heterogeneity; 75 to $100 \%$ : considerable heterogeneity ${ }^{(13)}$. The program Excel ${ }^{\circledR}$ was also used for organizing the studies in spreadsheets.

\section{Results}

The results identified 646 primary studies: 359 in MEDLINE/PUBMED, 131 in CINAHL, 62 in COCHRANE, 73 in WEB OF SCIENCE, none in the LILACS/BIREME, 14 in SCIELO and seven in manual searches. Of this total, 69 studies were pre-selected. Following independent analysis undertaken by two reviewers, only nine referred to the use of hydrocolloid dressings in wound healing, which were included in this research, as shown in Figure 2. The opinion of the third reviewer was requested so as to obtain consensus regarding the qualification of the nine articles selected.

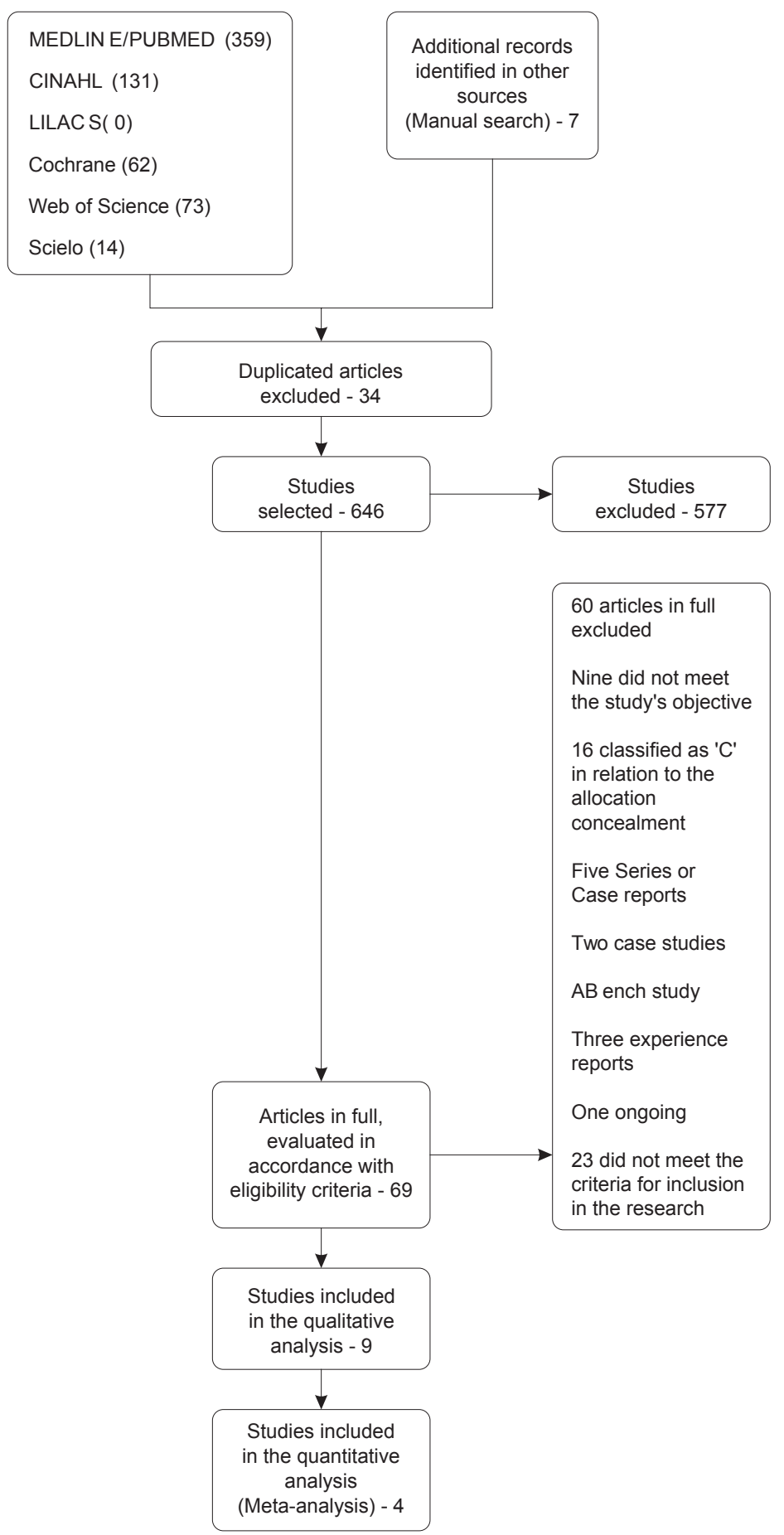

Figure 2 - Flowchart identification, selection and inclusion of the studies 
Figure 3 shows the summary of the studies selected and the scores obtained in the evaluation of the methodological quality using the Jadad Scale(16).

The year of publication of the studies included covered the period 1994-2004, with six publications in the decade of the 1990s and three between 2000 and 2004. All the studies were described as randomized and, together, totalled 695 patients. These were recruited in hospitals, nursing homes, long-term care centers, outpatient centers and in the community. The final analysis involved 639 subjects, of whom 380 were randomized for treatment with hydrocolloids, and the others for other topical therapies (whether in the experimental or control group).

Of the total number of PU included in the studies, 240 achieved total healing; of these, 131 were treated with hydrocolloids and 109 with the other therapies.

\begin{tabular}{|c|c|c|c|c|c|}
\hline $\begin{array}{l}\text { Article and } \\
\text { reference }\end{array}$ & $\begin{array}{c}\text { Type of study, number } \\
\text { of patients }\end{array}$ & Intervention & $\begin{array}{c}\text { Follow-up } \\
\text { time }\end{array}$ & $\begin{array}{c}\text { Outcome } \\
\text { Odds (Cl } 95 \%) \text { and } p\end{array}$ & $\begin{array}{l}\text { Jadad } \\
\text { Scale }\end{array}$ \\
\hline $\begin{array}{l}\text { E423 } \\
\text { Banks; Bale; } \\
\text { Harding, } \\
\text { 1994(17) }\end{array}$ & $\begin{array}{l}\text { Randomized clinical trial } \\
\qquad \mathrm{N}=40\end{array}$ & $\begin{array}{c}\text { Experimental: Polyurethane } \\
\text { Control: } \\
\text { Hydrocolloid }\end{array}$ & 6 weeks & $\begin{array}{c}\text { EG: } 12 \text { complete healings } \\
\text { CG: } 10 \text { complete healings } \\
\text { Odds } \\
1.50[0.42-5.24] \\
p=0.525\end{array}$ & 2 \\
\hline $\begin{array}{l}\text { E346 } \\
\text { Day et al., } \\
1995^{(18)}\end{array}$ & $\begin{array}{l}\text { Randomized clinical trial } \\
\qquad \mathrm{N}=103\end{array}$ & $\begin{array}{l}\text { Experimental: Triangular } \\
\text { hydrocolloid dressing } \\
\text { Control: } \\
\text { Oval hydrocolloid }\end{array}$ & - & $\begin{array}{c}\text { EG: } 17 \text { complete healings } \\
\text { CG: } 11 \text { complete healings } \\
\text { p=0.017 } \\
\text { Odds } \\
1.96[0.80,4.80]\end{array}$ & 2 \\
\hline $\begin{array}{l}\quad \text { E348 } \\
\text { Hondé; Derks; } \\
\text { Tudor, 1995(19) }\end{array}$ & $\begin{array}{l}\text { Randomized clinical trial } \\
\qquad \mathrm{N}=168\end{array}$ & $\begin{array}{l}\text { Experimental: Amino acid } \\
\text { copolymer membrane } \\
\text { Control: Hydrocolloid }\end{array}$ & 8 weeks & $\begin{array}{c}\text { EG: } 31 \text { complete healings } \\
\text { CG: } 23 \text { complete healings } \\
\text { Odds } \\
1.79[0.93,3.44] \\
p=0.089\end{array}$ & 2 \\
\hline $\begin{array}{c}\text { E312 } \\
\text { Bale et } \\
\text { al.,1997(20) }\end{array}$ & $\begin{array}{l}\text { Randomized clinical trial } \\
\qquad N=60\end{array}$ & $\begin{array}{c}\text { Experimental: Polyurethane } \\
\text { foam } \\
\text { Control: Hydrocolloid }\end{array}$ & 4 weeks & $\begin{array}{c}\text { EG: } 7 \text { complete healings } \\
\text { CG: } 5 \text { complete healings } \\
\text { Odds } \\
1.65[0.46,5.95] \\
p=0.44\end{array}$ & 2 \\
\hline $\begin{array}{c}\text { E314 } \\
\text { Thomas et al, } \\
1997^{(21)}\end{array}$ & $\begin{array}{l}\text { Randomized clinical trial } \\
\qquad \mathrm{N}=99\end{array}$ & $\begin{array}{l}\text { Experimental: Hydrocolloid } \\
\text { Control: Hydropolymer }\end{array}$ & 6 weeks & $\begin{array}{c}\text { EG: } 16 \text { complete healings } \\
\text { GC: } 10 \text { complete healings } \\
\text { Odds } \\
1.94[0.78,4.84] \\
p=0.0763\end{array}$ & 2 \\
\hline $\begin{array}{c}\text { E284 } \\
\text { Seeley; } \\
\text { Jensen; } \\
\text { Hutcherson, } \\
\text { 1999(22) }\end{array}$ & $\begin{array}{l}\text { Randomized clinical trial } \\
\qquad N=40\end{array}$ & $\begin{array}{l}\text { Experimental: Hydrocellular } \\
\text { Control: Hydrocolloid }\end{array}$ & 8 weeks & $\begin{array}{c}\text { EG: } 8 \text { complete healings } \\
\text { CG: } 8 \text { complete healings } \\
\text { Odds } \\
0.92[0.26,3.29] \\
p=0.89\end{array}$ & 2 \\
\hline $\begin{array}{l}\text { E554 } \\
\text { Burgos et al., } \\
2000^{(23)}\end{array}$ & $\begin{array}{l}\text { Randomized clinical trial } \\
\qquad \mathrm{N}=37\end{array}$ & $\begin{array}{c}\text { Experimental: Collagenase } \\
\text { Ointment } \\
\text { Control: Hydrocolloid }\end{array}$ & 12 weeks & $\begin{array}{c}\text { EG: } 3 \text { complete healings } \\
\text { CG: } 3 \text { complete healings } \\
\text { Odds } \\
1.07[0.19,6.13] \\
p=0.451\end{array}$ & 1 \\
\hline $\begin{array}{l}\text { E627 } \\
\text { Graumlich et } \\
\text { al., } 2003^{(24)}\end{array}$ & $\begin{array}{l}\text { Randomized clinical trial } \\
\qquad \mathrm{N}=65\end{array}$ & $\begin{array}{l}\text { Experimental: Topical collagen } \\
\text { Control: Hydrocolloid }\end{array}$ & 8 weeks & $\begin{array}{c}\text { EG: } 18 \text { complete healings } \\
\text { CG: } 15 \text { complete healings } \\
\text { Odds } \\
1.06[0.40,2.81] \\
p=0.893\end{array}$ & 2 \\
\hline $\begin{array}{l}\text { E169 } \\
\text { Hollisaz; } \\
\text { Khedmat; Yari, } \\
\text { 2004(25) }\end{array}$ & $\begin{array}{l}\text { Randomized clinical trial } \\
\qquad \mathrm{N}=83\end{array}$ & $\begin{array}{l}\text { Experimental: Hydrocolloid } \\
\text { Controls: (1) Phenytoin and (2) } \\
\text { simple dressing (gauze) }\end{array}$ & 8 weeks & $\begin{array}{c}\text { EG: } 23 \text { complete healings } \\
\text { CG 1: } 12 \text { complete healings }(\mathrm{Cl}=10.85-57.52) \\
p<0.01 \\
\text { CG 2: } 8 \text { complete healings }(\mathrm{Cl}=25.45-69.61) \\
p<0.005\end{array}$ & 2 \\
\hline
\end{tabular}

Figure 3 - Report of the studies selected, summary of the clinical trials and the scores obtained in evaluating the methodological quality using the Jadad Scale

\section{Meta-analysis}

Four studies were selected (E423 - Banks; Bale; Harding(17), E312 - Bale et $a^{(20)}$, E314 Thomas et $a^{(21)}$, and E284 Seeley; Jensen; Hutcherson ${ }^{(22)}$ ) for undertaking the meta-analysis, as they presented the use of hydrocolloids compared with foams as the intervention and the outcome as healing, as described below. 
In study E312 - Bale et $a^{(20)}, 60$ subjects treated with either hydrocolloid or a polyurethane foam dressing (experimental group) were monitored for a period of 30 days. Of the 31 subjects who used the hydrocolloid, five (16\%) wounds healed completely, compared to 7 (24\%) of the 29 subjects who received the polyurethane foam.

In study E423 - Banks; Bale; Harding(17) 40 patients were monitored over six weeks while they were treated with hydrocolloid and polyurethane dressings (experimental). Of the 20 subjects in the hydrocolloid group, 10 (50\%) obtained complete healing of the wound in the study period. In the foam group, the percentage of healing was $60 \%$ (12 subjects).

Thomas et $a^{(21)}$ (E314), evaluated 99 subjects treated with hydrocolloid (experimental group) and hydropolymer over six weeks. Of the 49 patients who received the experimental treatment, 33\% (16) of the PU healed totally, compared to $20 \%$ (10 of 50 ) who received the hydropolymer, which demonstrated a small advantage in favor of the hydrocolloid dressings.

In the study of Seeley; Jensen; Hutcherson(22) (E284) 40 patients were monitored over eight weeks, while they received treatment with hydrocolloid dressings and hydrocellular dressings (experimental group). Of the 39 subjects included in the analysis, 16 $(41 \%)$ presented a total cure of the lesions (eight in each treatment group).

The grouped results of the meta-analysis are presented in Figure 4.

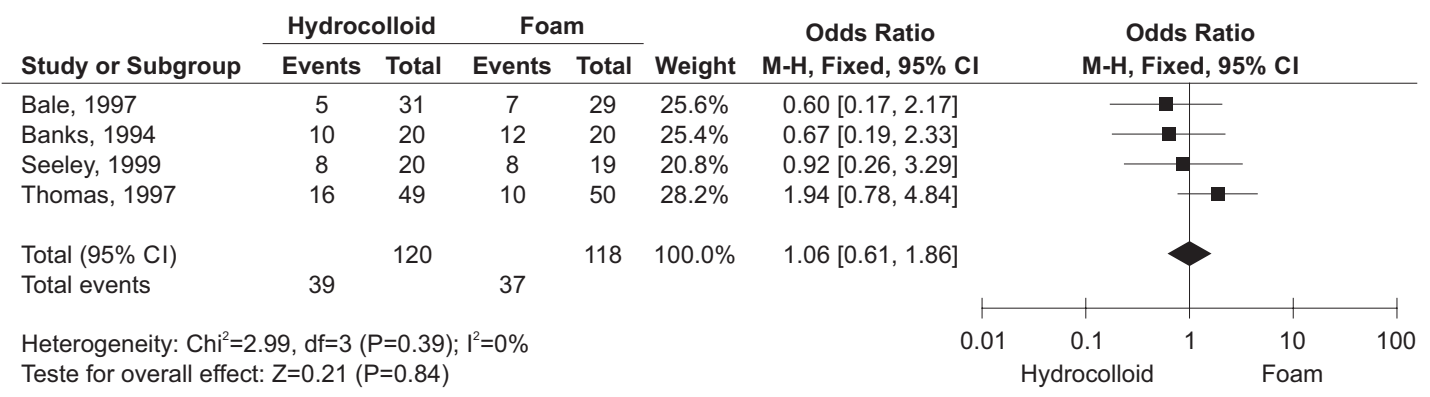

Figure 4 - Meta-analysis of the hydrocolloid dressing versus foams for healing

Due to the similarity between the results of the studies included in the meta-analysis, it was not possible to measure I2. In the same way, it was not possible to measure the heterogeneity due to the few studies it was possible to include in this study.

Regarding the outcome of healing, in using a fixed effect model, the absence of a statistically significant difference between the experimental and control groups was evidenced $(p=0.84 ;$ OR 1.06 , CI $95 \%$ 0.61-1.86).

Figure 5 presents the meta-analysis of the hydrocolloid dressing compared only with the polyurethane foam.

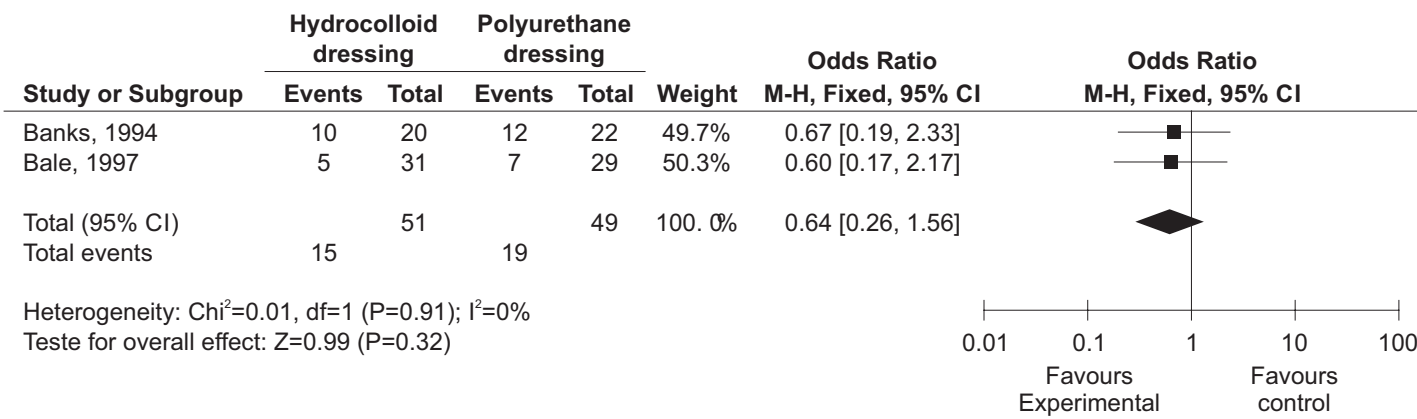

Figure 5 - Meta-analysis of the hydrocolloid dressing versus the polyurethane dressing for healing 
Although no statistically significant difference was evidenced between the experimental and control groups ( $p=0.324$; OR 0.64 , CI 95\% 0.26-1.56), it may be observed that the polyurethane dressing increases the possibility of healing in comparison with the hydrocolloid group, as evidenced by the positioning of the diamond in Figure 5. It stands out that, when the diamond is positioned to the right of the line of no effect, there is an increase of the outcomes studied with the use of the first intervention, represented in this study by the hydrocolloid and, when to the left, the use of the intervention reduces the occurrence of the outcome under study ${ }^{(26)}$. Thus, one may observe that the second intervention (the polyurethane dressing) increases the chances of the occurrence of the outcome studied - healing.

\section{Discussion}

In relation to the outcome "Healing", a total of 240 (35\%, n=671) PU achieved total reduction of the PU. It is noteworthy that $54.5 \%$ (131) of the PU which healed were treated using hydrocolloid dressings.

In study E169 - Hollisaz; Khedmat; Yari(25) it was observed that the hydrocolloid was more effective when compared with Gauze and tape $(p<0.005)$ and with topical phenytoin $(p<0.01)$.

In a systematic review of 29 clinical trials, it was possible to observe the superiority of hydrocolloids in relation to gauze, in relation to the number of healed $\mathrm{PU}$ and to the reduction of the wound's dimensions(27). Other studies(28-30) obtained similar results, although without a statistically significant difference between the dressings studied.

It stands out that hydrocolloids were also superior to the simple dressing in the treatment of other types of wounds, apart from PU, with a $76 \%$ possibility of obtaining better healing, although without a significant difference(31-32).

Compared with collagenase (E554 - Burgos et al) ${ }^{(23)}$, the number of ulcers which healed was similar between the two groups. One prospective randomized study emphasized a divergent result in evidencing that collagenase was more effective than treatment with hydrocolloids in PU located on the heels ${ }^{(33)}$. Of the total of 12 subjects who received collagenase, 11 (91.7\%) achieved success in the treatment, compared with seven $(63.6 \%)$ in the hydrocolloid group $(p<0.005)$.

In the meta-analysis of the studies E284 - Seeley; Jensen; Hutcherson(22),E312 - Bale et al(20),E314-Thomas et $a^{(21)}$ and E423 - Banks; Bale; Harding(17), in which hydrocolloid dressings were compared with foams (hydrocellular, hydropolymer and polyurethane), there was no statistically significant difference in the number of PU which healed ( $p=0.84$; OR 1.06, CI 95\% 0.61-1.86).

However, when comparison was undertaken only with the polyurethane foam (E423 - Banks; Bale; Harding(17) and E312 - Bale et $\left.a^{(20)}\right)$, although the superiority of the polyurethane dressing was not evidenced in healing $(p=0.32$; OR 1.57 , CI $95 \%$ 0.64-3.85), the meta-analysis revealed an increase in the chances of the occurrence of the outcomes studied. A clinical trial which compared the efficacy of hydrocolloids and a polyurethane foam demonstrated that there was no difference in the effectiveness of the two types of dressing when they were used in treating $\mathrm{PU}{ }^{(34)}$. A systematic review regarding foam dressings in the treatment of the diabetic foot also failed to present a difference in the number of healings when compared with hydrocolloids ${ }^{(35)}$.

In contrast, one systematic review ${ }^{(27)}$ which compared other dressings, such as foams, ascertained that the hydrocolloids were less effective regarding the number of wounds which healed, the healing time and the reduction of the area. A similar result was found for the treatment of other chronic wounds. In a clinical trial with 100 patients with venous ulcers, a significant superiority $(p<0.05)$ of hydrocellular foam was observed in relation to the hydrocolloid in the number of ulcers which healed( ${ }^{(36)}$.

It stands out that the grouping of the studies in the meta-analysis was compromised by the divergences in the interventions studied and in the measuring of the outcomes. In one systematic review on the use of special dressings in treating PU, the authors mentioned that the joint analysis of the 77 studies was hindered by, among other reasons, the disparities in the outcomes analyzed(37).

When compared with other special dressings, such as collagen (E627 - Graumlich et al)(24), statistically significant differences were not observed in the healing rates. The amino acid copolymer (E348 - Hondé; Derks; Tudor)(19) was more effective than the hydrocolloid dressing $(p=0.089)$.

A systematic review of dressings for venous ulcers did not find a significant difference between the hydrocolloids and collagen in the healing of the wounds(38). Another study mentioned that there was no proof of the efficacy of hydrocolloids in relation to other dressings in the treatment of diabetic foot ulcers ${ }^{(39)}$. 
Similarly, a systematic review concluded that the evidence is insufficient to consider any particular special dressing, among these hydrocolloids, superior to the others ${ }^{(40)}$. The studies described above indicate results similar to those offered in this study, whether for PU or other chronic wounds.

In the comparison between hydrocolloids in different shapes, study E346 - Day et al(18) evidenced the superiority of the triangular-shaped dressing in healing $(p=0.017)$ of sacral $P U$ in comparison with the oval hydrocolloids. A similar result was found by other authors ${ }^{(27)}$. This difference may be related directly to the shape, given that the difficulty in adapting dressings in the sacral region can compromise and reduce their performance(41). Thus, the triangular hydrocolloid dressing is better adapted to the region and, consequently, presents better results in healing.

\section{Conclusions and implications for clinical practice}

Based on the results found in this systematic review with meta-analysis, the following evidence was observed, in relation to the healing of PU following the adoption of the hydrocolloid dressing:

- the evidence is insufficient to assert that the efficacy of hydrocolloids is superior to that of other special dressings;

- one has to consider there to be a slight superiority of the polyurethane foam in PU healing, as evidenced by the meta-analysis. However, further studies are necessary for confirming this hypothesis;

- the present research does not justify the changing of clinical practice in relation to hydrocolloids, when compared with the other special dressings, as there was no significant difference in the rate of PU healing. However, when compared with the standard therapy (gauze and tape) adopted in most Brazilian health institutions, one can observe the superiority of hydrocolloids with a statistically significant difference, justifying its indication.

\section{The research's limitations}

Most of the studies included here worked with small samples, which may have compromised the detection of statistically significant differences between the dressings studied. Thus, with the aim of minimizing the margin of error and increasing the precision of the results found, further clinical trials with larger samples are suggested;
The short follow-up time (monitoring of four to 12 weeks) may have impaired the measuring of some outcomes, such as healing, given the chronicity of PU.

Due to the scarcity of information originating from randomized clinical trials of sufficient quality to indicate the efficacy of technologies such as hydrocolloids, the undertaking of further studies is justified, so that it may be established which products are most appropriate, as well as the real benefit of the special dressings, compared with each other, in treating PU.

\section{References}

1. Skorkowska-Telichowska k, Czemplik M, Kulma A, Szopa $\mathrm{J}$. The local treatment and available dressings designed for chronic wounds. J Am Acad Dermatol. 2013;68(4):117-26.

2. Laureano A, Rodrigues A. Cicatrização de feridas. Rev Soc Port Dermatol. 2011;69:355-65.

3. Lacci K, Dardik A. Platelet-Rich Plasma: Support for its use in wound healing. Yale J Biol Med. 2010;83:1-9.

4. Mestre T, Rodrigues A, Cardoso J. Cicatrização de feridas crónicas - Algumas opções terapêuticas. Revista SPDV. 2012;70(4):423-33

5. European Pressure Ulcer Advisory Panel (EPUAP) and National Pressure Ulcer Advisory Panel (NPUAP). Prevention and treatment of pressure ulcers: quick reference guide. 2009 [acesso 03 jan 2012]. Disponível em: http://www.epuap.org/guidelines/Final_ Quick_Treatment.pdf

6. Dorner B, Posthauer ME, Thomas D. The Role of Nutrition in Pressure Ulcer Prevention and Treatment: National Pressure Ulcer Advisory Panel White Paper [Internet]. National Pressure Ulcer Advisory Panel; 2009 [acesso em 06 jun 2011]. Disponível em: http://www. npuap.org/wp-content/uploads/2012/03/NutritionWhite-Paper-Website-Version.pdf

7. Cuddigan J, Berlowitz DR, Ayello EA. Pressure Ulcer in America: Prevalence, Incidence and Implications for the future. An Executive summary of the National Pressure Ulcer Advisory Panel Monograph. Advances in Skin \& Wound Care. 2001:14(4):208-15.

8. Matos LS, Duarte NLV, Minetto RC. Incidência e prevalência de úlcera por pressão no CTI de um Hospital Público do DF. Revista Eletrônica de Enfermagem [Internet] 2010 [acesso em 15 abr 2011] 12(4):71926. Disponível em: http://www.fen.ufg.br/revista/v12/ n4/v12n4a18.htm

9. Freitas MC, Medeiros ABF, Guedes MVC, Almeida PC, Galiza FT, Nogueira JM. Úlcera por pressão em idosos 
institucionalizados: análise da prevalência e fatores de risco. Rev Gaúcha Enferm. 2011;32(1):143-50

10. Fletcher J, Moore Z, Anderson I, Matsuzaki K. Pressure ulcers and Hydrocolloids. Made Easy. Wounds International [Intenet] 2011 [acesso em 17 fev 2014] 2(4). Disponível em: http://www.woundsinternational. com/pdf/content_10143.pdf

11. Reddy M, Gill SS, Kalkar S, Wu W, Anderson PJ, Rochon PA. Treatment of Pressure Ulcers: A Systematic Review. JAMA. 2008:300(22):2647-62.

12. Dealey C. Cuidando de feridas: um guia para as enfermeiras. 3 ed. São Paulo: Editora Atheneu; 2008. 240p.

13. Higgins JPT, Green S. Cochrane Handbook for Systematic Reviews of Interventions Version 5.1.0. [internet]. The Cochrane Collaboration [2011] [acesso em 10 jun 2012]. Disponível em: http://www.cochranehandbook.org

14. Santos CMC, Pimenta CAM, Nobre MRC. The PICO strategy for the research question construction and evidence search. Rev. Latino-am. Enfermagem. 2007;15(3):508-11.

15. Hulley SB, Cumming SR, Browner WS, Grady, DG, Newman, TB. Delineando a pesquisa clínica: uma abordagem epidemiológica. 3 ed. Porto Alegre: Artmed; 2008. 384p.

16. Jadad AT, Moore RA, Carrol D, Jenkinson C, Reynolds DJ, Gavaghan DJ, et al. Assessing the quality of reports of randomized clinical trials: Is Blinding necessary? Control Clin Trials. 1996:17:1-12.

17. Banks V, Bale SE, Harding KG. Comparing two dressings for exuding pressure sores in community patients. J Wound Care. 1994:3(4):175-8.

18. Day A, Dombranski S, Farkas C, Foster C, Godin J, Moody $M$, et al. Managing Sacral pressure ulcers with hydrocolloid dressings: Results of a controled, clinical study. Ostomy Wound Manage. 1995: $41(2): 52-4,56,58$.

19. Hondé C, Derks C, Tudor D. Local Treatment of pressure sores in the elderly: Amino Acid Copolymer Membrane versus Hydrocolloid Dressing. J Am Geriatr Soc. 1994:42(11):1180-3.

20. Bale S, Squires D, Varnon T, Walker A, Benbow $M$, Harding K. A comparison of two dressing I pressure sore management. J Wound Care. 1997: 6(10):463-66.

21. Thomas S, Banks V, Bale S, Fear-Price M, Hagelstein

$S$, Harding KG, et al. A comparison of two dressings in the management of chronic wounds. J Wound Care. 1997:6(8):983-6.
22. Seeley J, Jensen JL, Hutcherson J. A randomized clinical Study comparing a Hydrocellular dressing to a hydrocolloid dressing in the management of pressure ulcers. Ostomy Wound Manage. 1999 45(6):39-44, 46-7.

23. Burgos A, Giménez J, Moreno E, Lamberto E, Utrera M, Urraca EM, et al. Cost, Efficacy, Efficiency and Tolerability of Collagenase Ointment versus Hydrocolloid Occlusive Dressing in the Treatment of Pressure Ulcers. A Comparative, Randomised, Multicentre Study. Clinical Drug Investigation. 2000:19(5): 357-65.

24. Graumlich JF, Blough LS, McLaughlin RG, Milbrandt JC, Calderon CL, Agha SA, et al. Healing Pressure Ulcers with Collagen or Hydrocolloid: A Randomized, Controlled Trial. J Am Geriatr Soc. 2003:51(2):147-54.

25. Hollisaz T, Khedmat $H$, Yari F. A randomized clinical trial comparing hydrocolloid, phenytoin and simple dressing for the treatment of pressure ulcers. BCM Dermatology. 2004; 4:18.

26. Atallah NA, Castro AA. Curso de revisão sistemática e metanálise. [Internet]. São Paulo: LED-DIS/UNIFESP; 2002 [acesso em 09 mar 2011]. Disponível em: http:// www.virtual.epm.br/cursos/metanalise/

27. Heyneman A, Beele $H$, Vanderwee $K$, Defloor $T$. A systematic review of the use of hydrocolloids in the treatment of pressure ulcers. J Clinic Nursing. 2008:17(9):1164-73.

28. Xakellis GC, Chrischilles EA. Hydrocolloid versus saline-gauze dressings in treating pressure ulcers: a cost-effectiveness analysis. Arch Phys Med Rehabil. 1992:73(5):463-9.

29. Kim YC, Shin JC, Park CI, Oh SH, Choi SM, Kim YS. Efficacy of a hydrocolloid occlusive dressing technique in decubitus ulcer treatment: a comparative study. Yonsei Med J. 1996:37(3):181-5.

30. Chang KW, Alsagoff S, Tong K, Sim PH. Pressure Ulcers: Randomised Controlled Trial Comparing Hydrocolloid and Saline Gauze Dressings. Med ] Malaysia. 1998: 53(4):428-31

31. Ohlsson P, Larsson K, Lindholm C, Möller M. A costeffectiveness study of leg ulcer treatment in primary care. Comparison of saline-gauze and hydrocolloid treatment in a prospective, randomized study. Scand J Prim Health Care. 1994:12(1):295-99.

32. Shaileshkumar ME, Pramod MIRJI, Vishwanath G, Basarkod SI, Chhaya J, Rajani P. Clinical Trial to Assess the Efficacy of Hydrocolloid versus Paraffin Gauze Dressing for Split Thickness Skin Graft Donor Site Treatment. J Clin Diagn Res. 2012:6(1):72-5 
33. Müller E, Leen MWFV, Bergemann R. Economic evaluation of collagenase-containing ointment and hydrocolloid dressing in the treatment of pressure ulcers. Pharmacoeconomics. 2001:19(12):1209-19.

34.Banks V, Bale S, Harding K. The use of two dressings for moderately exuding pressure sore. J Wound Care. 1994:3(3):132-4.

35. Dumville JC, Deshpande S, O'meara S, Speak K. Foam dressings for healing diabetic foot ulcers. Cochrane Database of Systematic Reviews. 2011:7(9).

36. Rajput HI, Cullingworth L, Dunne T. Comparative evaluation of a hydrocellular foam wound dressing (Allevyn*) versus a hydrocolloid dressing in chronic lower limb venous ulceration. Association of Surgeons of South Africa Congress, 2000. S Afr J Surg. 2001:1(4).

37. Bouza C, Saz Z, Muñoz A, Amate JM. Efficacy of advanced dressings in the treatment of pressure ulcers: a systematic review. J Wound Care. 2005:14(5):193-9.

38. Palfreyman S, Nelson EA, Michaels JA. Dressings for venous leg ulcers: systematic review and meta-analysis. BMJ. 2007:335(7613):244-8.

39. Dumville JC, Soares MO, O'meara S, Cullum N. Systematic review and mixed treatment comparison: dressings to heal diabetic foot ulcers. Diabetologia. 2012:55: 1902-10.

40.Bouza C, Muñoz ABS, Amate JM. Efficacy of modern dressings in the treatment of leg ulcers:A systematic review. Wound Repair and Regeneration. 2005:13:218-29.

41. Torra B, Velenzuela AR, Ferrer PJ, Cano FF. Úlceras por presion em el sacro. Evaluación multicêntrica de um apósito hidrocoloide hidro-regulador específico. Rev Enferm. 1999:22(3):223-30. 